\title{
Adrlanus van Selms, deeltydse dosent 1938-1962
}

\author{
J P Oberholzer \\ Universiteit van Pretoria
}

\begin{abstract}
Adrianus van Selms, part-time lecturer 1938-1962

Van Selms came to Pretoria in 1938 as a senior lecturer in Semitic Languages in the Faculty of Arts. At the same time he accepted an appointment in the Faculty of Theology as a part-time lecturer in the one-year course, Biblical Archaeology. Students thus enjoyed his inspiring academic influence for a considerable period of their sojourn at the University. In this article particular attention is given to Van Selms's view of Holy Scripture and the way in which he integrated faith and knowledge. It is also shown that, from the sixties onward, ecumenical theology tends to become the most prominent feature in his theological work, with little attention left for salvation history, an important aspect in his earlier work. The esteem in which he is held by our Faculty is shown by the dedication of HTS $41 / 2$ (May 1985) to him, and by the establishment of the Van Selms Reading Room in which a part of his valuable library is kept.
\end{abstract}

Van Selms was 'n alumnus van Utrecht, gepromoveer in 1933 onder H W Obbink, die godsdienshistorikus, met 'n proefskrif oor die Babiloniese terme vir sonde. Sy kontak met F M Th de Liagre Böhl, destyds van Leiden en met Albrecht Alt tydens 'n verblyf in Palestina in 1926, beteken vir hom baie en help hom vorm tot die formidabele geleerde wat hy geword het. Hy is gebore op 22 Januarie 1906 in Amster- 
dam en begin in 1923 met die akademiese studie. Na die kandidaatseksamens in Teologie en Semitiese Tale word hy predikant te Hansweert (Zeeland) in 1930 en in 1935 te Culemborg. Toe hy in 1938 in Pretoria die pos van senior lektor in Semitiese Tale aanvaar as assistent van Gemser, was hy reeds 'n gevestigde akademikus en outeur - kwaliteite wat hom tot ongekende hoogtes sou voer (Loader 1984:17; Van Wyk 1985:172v). 'n Behoorlike oorsig oor Van Selms se lewenswerk het nog nie verskyn nie, miskien omdat hy so baie geskryf het, maar dalk eerder omdat hy so 'n veelsydige geleerde en so 'n skerpsinnige, diepsinnige teoloog was. Die kort waarderings wat wel verskyn het, gee almal blyke van vlugtige aanraking met 'n omvangryke en ingewikkelde tema (Fensham 1984; Jongeleen 1984; Van der Woude 1984; Loader 1984; Oberholzer 1985; Van Wyk 1985; Loader 1989).

Dit is tiperend dat sy eerste bydrae in Die Hervormer, 'n Kersfees-oordenking wat op 30 November 1938 verskyn, nege maande na sy aankoms, alreeds in Afrikaans was. Dit was bowendien nie sy eerste publikasie in Afrikaans nie. Reeds op 22 April 1938 verskyn 'n Afrikaanse artikel van hom in Die Huisgenoot, gevolg deur 'n tweede op 1 Julie. Die artikel oor die vonds by Ugarit in die Almanak (in Hollands) van 1938 het die redakteur al vanuit Holland bereik. Wie met Van Selms wil kennis maak deur middel van sy geskrifte, sal dan ook veel meer ontmoet as net 'n kenner van die Ou Nabye Ooste en die Ou Testament. Ook die sistematiese teoloog kom te voorskyn, met vrymoedige aansluiting by die gereformeerde vadere en by Barth maar met veel wat sprankelend oorspronklik gedink en geformuleer word, die innig gelowige prediker, fors en vaardig met tong en pen, die ensiklopediese geleerde wat in baie opsigte die laaste van sy soort maar dan ook 'n keurvoorbeeld van die soort was en in alles met 'n vrolike, enorme werkywer.

Van Selms het met sy koms na Pretoria in 1938 tegelyk ook dosent in die Fakulteit Teologie (Afd A) geword, verantwoordelik vir die eenjarige kursus in Bybelse Argeologie wat in die BD 1-jaar aangebied word. Dié taak het hy behartig tot 1962 toe hy in konflik met die Algemene Kerkvergadering en die Kommissie van die Algemene Kerkvergadering die status van dienaar van die Woord, wat hom deur die Kommissie verleen is in 1938 met die oog op die dosentskap in die Fakulteit, neergelê het (Joh Dreyer 1962). Die studente van die Fakulteit het hom dus as dosent ervaar gedurende die BA- sowel as die BD-studie, dit is vir minstens drie en in baie gevalle vir vier van die studiejare, afhangend daarvan of die student twee of drie jaar Hebreeus geneem het. Bowendien het hy ook nog soms die lesings in Ou-Testamentiese Eksegese waargeneem wanneer Gemser met verlof was. In die waarderings van oud-studente waarna bo verwys is, kom terme en sinne soos die volgende voor: 
- ' [A] biblical exegete with highly original ideas, versatile, remarkable memory, one of the truly universals, a practising Christian with a deep feeling of sympathy for the less privileged in South Africa' (Fensham 1984);

- '...true to the ethical tradition of which he was proud to be regarded a representative, vast knowledge, affection for the Jews, critical stance about the communion of saints and the colour problem, enormous influence (Loader 1984);

- '...verstommende erudisie, vermoë om op 'n byna rabbynse wyse 'n wye verskeidenheid van uiteenlopende onderwerpe bymekaar te bring. Die hart van Van Selms se lesings was om sy studente 'n respek vir die Hebreeuse Bybel te leer en om terselfdertyd die kritiese gees...in hulle wakker te maak' (Loader 1989);

* '...brilliant geleerde, gelovige, veelzijdig mens, begenadigd hoogleraar, welsprekend kanselredenaar, schrijver van vele boeken en artikelen en eenvoudig mens' (Jongeleen 1984);

* '...uitmuntende kwaliteit, publikasiedrif, opwindend en prikkelend, aangename kollega, fenomenale geheue, sprankelende oorspronklikheid en diepte van insig' (Van Wyk 1985);

* 'Gedeë, briljante akademikus, uitnemende filoloog en teoloog, inspirerende dosent, hartstogtelike prediker en gelowige, vurige vaderlander, vaardige en diep gees, fenomenale geheue; (Oberholzer 1985);

* '...briljant geleerde, ongelooflijke eruditie, grote didactische gaven, encyclopedische kennis, vroom Christen, mildheid van wysheid. Wetenschap en geloof waren voor hem geen tegenstellingen, maar geïntegreerde grootheden. Inderdaad grootheden!' (Van der Woude 1984).

Hierdie getuienis dui op 'n persoon van meer as gewone formaat. So was dit inderdaad. Sy biograaf, wat hopelik nie te lank sal wag om te voorskyn te kom nie en hopelik oor die balans en vermoë daartoe sal beskik, sal 'n wye en avontuurlike veld moet betree.

In my boekery het bewaar gebly die aantekening- en werkboek wat ek in 1947 vir Hebreeus 3 gebruik het. Die klaswerk was Prediker 1-5 en Miga 1-5 en die selfstudie Psalm 62-66, Job 12-16 en Jeremia 8-12. Daarnaas staan as selfstudie aangeteken Palache se 'Inleiding in den Talmud' en sy 'De Hebreeuwsche literatuur van de na-Talmudiese tydvak'. Vir die lesings in die byvak wat saam met Hebreeus 3 geneem moes word, is daardie jaar gebruik gemaak van A S Geyser, wat ons Siries laat lees het en daarby Baumstark se 'Geschichte der Syrischen Literatur' vir selfstudie voorgeskryf het. Hierdie patroon het deur die jare ongeveer dieselfde gebly: ongeveer tien Bybelhoofstukke klaswerk en vyftien vir selfstudie, met 'n hoeveelheid 
leeswerk. Die byvak in die derde jaar het gewissel tussen die verskeie Semitiese Tale: Aramees met sy dialekte, Arabies, Akkadies en Ugarities. By so 'n voorstudie het die Bybelse Argeologie nog 'n verdere verryking beteken. Vir selfstudie is voorgeskryf Albright se 'Archaeology and Religion of Israel' en gedeeltes uit Volz se 'Biblische Altertümer' en Benzinger se 'Hebräische Archaeologie'. In die klas het ons die briewe van Lakis gelees en boonop oor Elefantine en Ugarit aantekeninge afgeneem. (Omdat ek stadig skrywe, is die aantekeninge nie so volledig nie.) Dat egter in die loop van die studie 'n akademiese rykdom versamel is, staan vas, en ook dan die so nodige akademiese nederigheid. Kenmerkend is ' $n$ aantekening by Prediker 4:13-16 waar Van Selms verwys na allerlei menings wat van vroeg af gehuldig is oor die identiteit van die jongman en die koning in die betrokke gedeelte. Dit word afgesluit met die volgende: 'A v S verwerp alles. Hertzberg: Josef pas ook nie goed in nie. A v S: Ignoramus et fortasse ignorabimus.' Uit die aantekeninge oor Miga wat ewe-eens in 1947 (NB) afgeneem is, kom onder andere die volgende: 'Miga 'n sosiale profeet. Sy kritiek word fel teen priesters en quasi-profete wat geen kritiese houding inneem teenoor die kontemporêre toestande nie.'

'n Bybelse eksegeet met hoogs oorspronklike idees' - so het Fensham geoordeel. Tot vandag toe is die kommentare op Bybelboeke wat deur Van Selms nagelaat is, kosbare en pakkende leesstof, vir sover dan 'n kommentaar pakkend kan wees. In 'Een woord vooraf' by II Kronieken in Tekst en Uitleg skryf hy: 'Na zes jaar oorlog en krijgsgevangenschap was het den schrijver een verkwikking, na belangriker zaken terug te keeren. Moge dóór de vaalheid, die nu eenmaal onvermijdelik een werk als dit karakteriseert, toch iets van zijn dankbaarheid doorstralen' (Van Selms 1947a). Naas die noukeurige aandag aan teks, taal en konteks was daar by hom steeds 'n vanselfsprekende vraag na die boodskap of teologie van die boek, wat in sy ouer werke nie opgehou het by die teologiese struktuur en gedagtes in die boek self nie maar telkens wyer uitgekring het na die breër konteks, en wel na die konteks van die Bybel in sy geheel. Dit het, naas 'n bepaalde hermeneutiese patroon, ook ' $n$ kritiese ingesteldheid ingehou, voortkomend uit 'n kanon-denke wat in eg reformatoriese baan Skrifdenke (vanuit die totaliteit) en nie teksdenke is nie. Soos hy hierdie patroon en denke in sy jeug geformuleer het, so het dit stand gehou tot in die vyftigerjare. In die artikelreeks oor die toekoms van Israel volgens die Bybel, wat in 1939-1940 in Die Hervormer verskyn, praat hy onbevange van die hele Ou Testament as voorbereiding vir die koms van Christus. Hy voeg daaraan toe: '[M]aar met Hom het die Nuwe Verbond gekom; die oue is verby; dit het slegs in sover waarde as wat dit heenwys na Christus' (Van Selms 1940b:15). In ooreenstemming hiermee stel hy in 1948 dat nie 'net die uitdruklike Messiaanse profesieë nie maar ook die geheel van die offerdiens in Israel sien op Hom wat die sonde van 
die wêreld wegneem' (Van Selms 1948f:4). In die inleiding tot die Esra-Nehemiakommentaar ( $T \& U$ ) handel hy krities oor die partikularisme en selfisolasie wat hom van die Israel van dié tyd en plek meester gemaak het, maar kom dan tot die slotsom:

Niettemin moet men erkennen, dat de inkapseling van Israel een noodzakelijke factor in die heilsgeschiedenis is geweest. Het heeft God behaagd, op deze wijze een volk voor te bereiden op den komst van zijn Zoon. Bovendien kon Israëls erfgoed, het Woord Gods in wet en profeten, alleen op deze wijze bewaard blijven voor de algemene vergetelheid, die de verdere oud-Oostersche litteratuur tot in de negentiende eeuw heeft bedekt. De kostbare schat werd geborgen in aarden vaten; het is de tragiek van Israël geweest, dat het in zijn beslissende stonde het aarden vat heeft willen behouden, liever dan dat het Woord Gods tot de heidenen zou komen (Hand 22:21,22).

(Van Selms 1935a:23)

Voeg hierby die paragraaf wat hy in 1939 in die inleiding op die Kroniekboeke soos volg formuleer:

Men kan zich afvragen, of de prediking van den Kronist niet aanleiding worden kan voor een geschiedenis-filosofie, waarin wat geloofsuitspraak was, tot een systematische theodicee, en daarmee tot kettery, wordt gemaakt. Dat is inderdaad mogelijk, zoodra men de eenheid der gansche Heilige Schrift uit het oog verliest, en het boek der Kronieken isoleert, in plaats van voortdurend ook aan Job indachtig te zijn. Maar deze loochening van de eenheid der Heilige Schrift is in zichzelf al de oervorm van alle kettery. Daarvoor kan ons slegs bewaren, wat Haitjema (Het Woord Gods in de moderne cultuur, 1931, p $132 \mathrm{e} \mathrm{vv}$ ) theologische Bijbelkritiek heeft genoemd; dat is in wezen niets anders dan de handhaving der eenheid van Gods Woord.

(Van Selms 1939a:35)

Dié Skrifbeskouing word ook nog eksplisiet deur Van Selms gestel in 'n voordrag voor die predikantevergadering op 29 Februarie 1956 (Van Selms 1956b). Die voordrag was getitel 'Die plek van Israel in ons teologies-kerklike beskouing' en vertoon ' $n$ fynheid van eksegetiese waarneming wat moeilik elders geëwenaar word. Die voordrag moet in sy geheel gelees word om die rykdom daarvan ten volle te smaak. Wat volg, is nie ' $n$ weergawe nie maar bloot 'n paar flitse om aan te spoor tot verdere kennisname: Ons, lede van die kerk, sien Israel anders as wat Israel 
homself teenwoordig sien. Tog, alles wat ons van Israel weet, kom uit die selfgetuienis van Israel. 'n Christus buite Israel, los van Israel, is 'n onbestaanbaarheid. Tog, hierdie Jesus wat deur ons as die Christus bely word, is deur Israel verwerp, en kon ook net deur Israel verwerp word. Ons kan dus net een benadering volg, naamlik dié op grond van die Heilige Skrif, wat wel histories die selfgetuienis van Israel is, maar tegelyk veel meer is: die oorkonde van Gods weg met Israel en so dus die enigste werklike bron vir ons kennis van die heilsgeskiedenis. Maar dan, die kerk benader die Heilige Skrif van Christus uit. Verder haal ek eerder woordeliks aan:

Christus is die principium canonicitatis, en hierdie Reformatoriese beginsel bepaal nie maar net die omvang van die Kanon nie, maar ook ons benadering van die onderdele daarvan.

Ons sou met die Ou Testament niks te doen het nie, as ons nie uit die Nuwe Testament sou leef nie. Ons benader die Ou Testament van die Nuwe Testament uit, en nie omgekeerd nie. Ons glo Christus nie om die Skrif ontwil nie, maar ons glo die Skrif om Christus ontwil. Ons vind Christus in die Nuwe Testament, en vandaar uit kan ons teruggaan na die Ou Testament, om daar in profesie en voorafskaduwing die Messias weer te vind. Sonder die Nuwe Testament is dit vir ons onmoontlik om die Ou Testament Christelik te verstaan.

Dit beteken dus dat ons as kerk en as teoloë nie regstreeks na die Ou Testament mag gaan nie, maar dit altyd oor die weg van die Nuwe Testament moet bereik. Ook histories gesien is dit nie anders as billik nie. Die Ou Testament is nie vir ons geskryf nie, maar vir Israel, en dit raak ons net in sover as ons deur die Christus van Israel ook deel van Gods weg met Israel kry.

Dit beteken dus ook dat ons geen gegewens uit die Ou Testament, wat in die Nuwe Testament nie meer opgeneem word nie, regstreeks, buite die Nuwe Testament om, op ons lewe en verwagting mag betrek nie. Doen ons dit tog, dan handel ons nie maar net asof daar geen geskiedenis bestaan nie, maar ons ontken selfs die prinsipiële betekenis van die feit dat heilsgeskiedenis geskiedenis is. Dit is die kettery van die Biblisisme, wat nie so onskuldig is as wat party mense dink nie. Die onderstelling en tegelyk konsekwensie daarvan is dat die Christus agter die Skrif verdwyn.

Betekenisvol is ook die drie voetnote wat Van Selms by sy beskouing soos aangehaal plaas. Die eerste laat blyk wat ons reeds vroeër uitgespreek het, naamlik sy geneentheid teenoor die teologie van Karl Barth: 'As die leser dit Christomonisme wil noem, dan is die skrywer bly dat hy dieselfde verwyt as die grootste teoloog van 
hierdie eeu mag dra.' Die tweede voetnoot, by die vermelding oor die heilsgeskiedenis, lui: 'Daarmee word dan die enigste singewing van die menslike geskiedenis onmoontlik.' Die derde sluit aan by die gevaar van die Biblisisme wat Christus agter die Skrif laat verdwyn: 'Dan gaan ons met die ICCC van "skrifgelowig" in plaas van met die geloofsbelydenis van "Christusgelowig" praat.'

Tot hiertoe was 'n Van Selms aan die woord wat tegelyk hartstogtelik getuie was, prediker en teoloog tegelyk. Die Skrifbeskouing wat hy so sonder skroom uitgespel het, kom egter nie in sy latere geskrifte weer so aan die orde nie. Oor die rede daarvoor kan ons net gis. Oor die geheel van die Ou-Testamentiese wetenskap het van die sestigerjare af ' $n$ bepaalde terughoudendheid hom laat geld. Die hermeneutiek het 'n ingewikkelde bedryf geword. Die ekumeniese teologie het homself aangemeld. Die helder geskal van die nieu-reformatoriese wekroep waarvan Karl Barth die belangrikste beiaardier was, het verseild geraak tussen ander klanke. Ek waag my nie hier aan 'n verklaring van wat vir my lyk na 'n toonverandering in die skryfwerk van Van Selms nie. Ek vestig alleen die aandag daarop dat in sy Genesiskommentaar wat nog in die sestigerjare verskyn, die ekumeniese teologie hom sterk laat geld het. Die apologetiese tendens in hierdie kommentaar is vroeg al uitgewys (Du Plessis 1967/1968:152). Jodedom en Islam staan hier langs Christendom as erfgenaam van Genesis. Die eenheid van die mensdom, die noodsaak van 'n regsorde en die sedelike roeping van nasies en persone is hier die prominente, terwyl die onbevange heenwysing na die Christus wat alles nuut sou maak, nie voorkom nie (Van Selms 1967b:301).

Net so is in die Jobkommentaar in die Tekst en Toelichting-reeks streng gehou by die gedagtewêreld van die boek self. Die boek Job is vir die Christelike gemeente van groot waarde, veral dan vanweë die opname van lyne uit die boek in die Brief van Jakobus (Van Selms 1984:209). Die samevatting van die prediking van die boek op bladsy 27 is waardevol, maar dit word aan die gebruiker van die kommentaar oorgelaat om 'n teologiese verband met die Christus van die Nuwe Testament te vind.

Die heilshistoriese ontbreek nie geheel en al in hierdie latere werk nie (Van Selms 1974c:138), maar dit het skaars geword. Toekomstige ondersoek moet dié aspek noukeuriger nagaan. Die uitstaande kenmerk van al die kommentaarwerke is die noukeurige aandag aan detail in teks en taal, net soos dit ook die geval is in sy werk op die gebied van die Ou Nabye Ooste. As 'n mens dit sou wou waag om Van Selms se blywende invloed in die Departement Ou-Testamentiese Wetenskap in enkele woorde saam te vat, sal dit juis in die twee sake lê wat ek probeer uitwys het: noukeurige deeglikheid in die filologie en integrering van wetenskap en teologie. 
Soos in die geval van Gemser, het die gesprek met Van Selms nie by sy dood geëindig nie. Die herdenkingsnommer HTS 41/2 en die inrigting van die Van Selms leeskamer in die Fakulteitsgebou, waar 'n deel van sy boekery gevestig is, is getuies van waardering en hoogskatting. Dit spreek vanself dat dit veral sy geskrifte sal wees wat telkens weer aandag sal vra, nie die minste nie dié waarin hy ons tot selfkritiek oproep.

\section{Literatuurverwysings}

Dreyer, Joh 1962. Die bedanking van prof A van Selms. Die Hervormer, Julie 1962, bl 25.

Du Plessis, J G 1967/1968. Boekbespreking. HTS 23/3 \& 4, 152.

Fensham, F C 1984. Prof dr Adrianus van Selms. JNSL 12, 1-3.

Jongeleen, C 1984. In memoriam prof dr A van Selms. Nederlandse Post, Junie 1984, bl 2-3.

Loader, J A 1984. The writings of professor Adrianus van Selms. JNSL 12, 5-17.

--- 1989. Vanselmiaanse indrukke. Die Henormer, Desember 1989, bl 7.

Oberholzer, J P 1985. Prof dr A van Selms. Almanak 1985, 67.

Van der Woude, A S 1984. In memoriam Prof dr A van Selms 1906-1984. Kerk en Theologie 35, 265-267.

Van Wyk, W C 1985. Professor Adrianus van Selms. HTS 41, 171-182.

\section{Publikasies van A van Selms}

By die opstelling van hierdie lys is met dank gebruik gemaak van J A Loader (1984) en W C van Wyk (1985) se publikasies. Vertalings, herdrukke en resensies is nie opgeneem nie. Hoewel talle titels hier nuut opgeneem is, is die lys steeds onvolledig. Van Selms se publikasies word hier in kronologiese volgorde aangebied:

1927. Indrukken van de zomerconferentie 11-16 Juli 1927. Eltheto 81, Aug 1927, 342-350.

1933. De Babylonische termini voor zonde en hun betekenis voor onze kennis van het Babylonische zondebesef. Wageningen: Veenman \& Zonen.

1934a. De zonden der jeugd. NTS 17, 344-349.

1934b. Opmerkingen over het religieuze taalgebruik der samasteksten. Mededeelingen EOL, 21-32.

1934c. De archaeologie in Syrië en Palestina. Jaarbericht EOL 2, 35-38.

1935a. Ezra en Nehemia. (T \& U.) Groningen: J B Wolters. 
1935b. Weenen als aanvangsrite. NTS 18, 119-127.

1935c. De archaeologie in Syrië en Palaestina. Jaarbericht EOL 3, 107-110.

1936a. De archaeologie in Syrië en Palaestina. Jaarbericht EOL 4, 207-211.

1936b. Hoe lezen wij het Oude Testament? OEV 1936, 10-27.

1937a. De Zondag tussen Farizeïsme en Libertinisme. Nijkerk: Callenbach.

1937b. Solidair! Den Haag: Boekencentrum.

1937c. De opgraving van Lachis. NTS 20, 41-57.

1938a. De Bijbel in het gezin. Zeist.

1938b. De plaats van het Oude Testament in de verkondiging. NTS 21, 34-52.

1938c. Evangelie en wet in de exegese van het Oude Testament. OEV 13, 88-104.

1938d. Kersfeesoordenking (Luk 2:12). Die Henormer, 30 November 1938, bl 7-9.

1938e. Een tekst uit het tempelarchief van Ugarit. Almanak, 129-139.

1938f. 'n Egiptiese beeldjie uit die dae van Moses. Die Huisgenoot, 22 April 1938, bl 21.

1938g. Dokumente meer as 42 eeue oud. Die Huisgenoot, 1 Julie 1938, bl 37, 57.

1938h. Ugarit: 'n Nuwe taal en 'n nuwe literatuur. UP Wetenskaplike Blad 1, 33-43.

1939a. I Kronieken. (T \& U.) Groningen: J B Wolters.

1939b. Die kerk bo Golgotha en die tuin van Josef van Arimathea. Almanak, 3345.

1939c. De brieven van Lakîs. Jaarbericht EOL 7, 84-88.

1939d. Eine neue Gudea - inschrift. AfO 13, 62-63.

1939e. Vraebus: Sal ons ons familielede in die hemel sien? Die Hervormer 25 Oktober 1939, bl 21-22.

1939f. Vraebus: Is die feit dat iemand in ellende verkeer ' $n$ bewys dat hy geen kind van God is nie? Die Hervormer 29 November 1939, bl 19.

1939g. Die toekoms van Israel volgens die Bybel. Inleiding. Die Hervormer 29 Desember 1939.

1939h. Vraebus: Is die Evangelie aan die Dode verkondig. Die Hervormer 27 Desember 1939, bl 11-13.

1940a. God en die menschen. Zeist. Amsterdam: Ploegsma.

1940b. Die toekoms van Israel volgens die Bybel. Die Hervormer 31 Januarie 1940, bl 15-17.

1940c. Die toekoms van Israel volgens die Bybel. Die Hervormer 27 Maart 1940, bl 7-9.

1940d. Die toekoms van Israel volgens die Bybel. Die Hervormer 24 April 1940, bl 9-10.

1940e. Vraebus: Die standpunt van die kerk oor die leer van Darwin. Die Hervormer 31 Januarie 1940, bl 17-18. 
1940f. Vraebus: Uitlegging van Openbaring 17, in besonder na die betekenis van die olie, die ontugtige vrou en die konings. Die Henormer 24 April 1940, bl 14-15.

1940g. Vraebus: Kan afgestorwenes soos beweer word na die aarde terugkeer (nie in die vlees nie, maar in die gees)? Die Henvormer 29 Mei 1940, bl 16-17.

1940h. Vraebus: Oor Spiritisme, metodisme en kalvinisme. Die Hervormer 26 Junie 1940, bl 10-11.

1940i. Vraebus: Die rots, die koperslang, die ban en die begrawing deur die doop in die dood. Die Hervormer 31 Julie 1940, bl 10-12.

1940j. Vraebus: Mense wat opgevaar het na die hemel. Die Hervormer 28 Augustus 1940, bl 15.

1946a. Vaderlandsliefde in Oud-Israel. HTS 2, 166-178.

1946b. Nog 'n keer: Die Christelike kerkjaar. Die Hervormer 20 Junie 1946, bl 4-5.

1947a. II Kronieken. (T \& U.) Groningen: J B Wolters.

1947b. Een boekreligie. De vereering van de rol van Abisa door de Samaritanen. NTT 1, 193-203.

1947c. Die getalle-trap-spreuk: 'n Semitiese stylfiguur. HTS 4, 1-20.

1947d. Rabbula van Edessa, 'n Siriese parallel van Augustinus. HTS 4, 95-118.

1947e. Die Heilige Gees, die Heer en Lewendmaker. Die Hervormer 20 Mei 1947, bl 3-4.

1948a. Licht uit Licht: Het Christelijk geloof naar de belijdenis van Nicea. Amsterdam: Ploegsma.

1948b. Ragel se lis en Jakob se eerlikheid. Pretoria Jewish Review April 1948, bl 10.

1948c. Preutsheid in Kronieke. HTS 4, 133-144.

1948d. Geregtigheid as 'n Bybelse begrip. HTS 4, 152-163.

1948e. Die koningsbede as element in die kroningsritueel. HTS 5, 40-48.

1948f. Christus in Levitikus. Die Hervormer 20 Julie 1948, bl 4-6; 20 September 1948, bl 3-4.

1948g. 'n Argeologiese sensasie. HTS 4, 181-184.

1948h. Die invloed van die Ou Testament op die Afrikaanse kultuur en lewensvorme. Books and Writers 57-64.

1949a. Willem Sluiter en sy gemeente. Almanak 79-95.

1949b. Die oorname van die harem deur 'n nuwe koning. HTS 5, 25-41.

1949c. Stoterige bulle in die Bybelse en Babyloniese reg. Pretoria Jewish Review, Sept/Okt 1949, 16.

1949d. Die noodsaaklikheid van voortgesette studie. Die Hervormer Desember 1949, bl 8.

1949e. Een lapsus van Calvijn. NTT 4 (1949-1950), 413-415. 
1950a. Gezegende Sleur. Den Haag.

1950b. Toeligting by die kerklike jaarkring en ander gedenkdae. Almanak, 65-69.

1950c. Vollenhove se kruistriomf. Die lydingsgang van 'n gedig. Almanak, 123132.

1950d. Die oudste Jerusalem. Die Hervormer Januarie 1950, bl 1, 8.

1950e. Studiemateriaal van die Sondagskoolonderwyser (opsomming van 'n referaat). Die Hervormer Julie 1950, bl 9.

1950f. Die nuwe Jesajarol. Die Hervormer September 1950, bl 1.

1950g. The best man and bride. From Sumer till St John, with a new interpretation of Judges, chapter 14 and 15. JNES 9, 65-75.

1950h. The Dead Sea Scrolls. Pretoria Jewish Review May 1950, 3,14; June 1950, 2, 14.

1950i. The goring ox in Babylonian and Biblical Law. Archiv Orientalni 18, 321330.

1950j. Leersuccessie als gezagsvorm. NTT 5 (1950-1951), 257-276.

1951a. Veelheid van name by Judese konings. HTS 7, 141-163.

1951b. Tekstcritiek en exegese in de behandeling der Psalmen. $K \& T 2,76-96$.

1951c. Egypt and the Bible. Yehuda's work evaluated. Jewish Affairs, September 1951, 29-32.

1951d. Psalm 137: By die riviere van Babel. HTS 8, 7-8.

1951e. A short way to Boghazköy. Pretoria Jewish Review, April 1951, 19.

1951f. Die Kort Begrip en die Katkisasie. Almanak, 40-51.

1951g. Arabies - Afrikaanse Studies I. 'n Tweetalige (Arabiese en Afrikaanse) kategismus. Amsterdam: Noord-Hollandsche Uitgevers Mij.

1951h. Wie achter is moet voorgaan: Over de Nederlandse Geloofsbelydenis. Den Haag: Boekencentrum.

1952a. Die stad in die 1sraelitiese voorstellingslewe. HTS 8, 79-89.

1952b. 1slamic literature in Afrikaans. The Muslim Digest May 1952, 16-21.

1952c. A popular work in the newly found 'Dead Sea' manuscripts. Jewish Affairs, August 1952, 33-34.

1952d. Die geboortestad van Jan van Riebeeck. Almanak, 35-53.

1952e. Die Calvinisme van die eerste nedersetting. Die Henormer April 1952, bl 8, 10.

1952f. Waar bou ons die orrel? Die Hervormer, April 1952, bl 9, 10.

1953a. Die 'gemengde huwelik' in die Ou Testament. HTS 9, 34-47.

1953b. Die kontinuïteit van die kerk onder Ou en Nuwe Verbond. HTS 9, 93-100.

1953c. Die oudste boek in Afrikaans. Hertzog-annale 1953, 61-103. 
1953d. Verslag van die eerste konferensie van orreliste, predikante en kerkrade... gereël deur die Raad vir Kerkmusiek. Die Hervormer Julie 1953, bl 7, 10.

1953e. Korrespondensie: oor foto in Die Hervormer. Die Hervormer, Julie 1953, bl 8.

1953f. Leemtes in ons Gesangboek. Almanak, 39-49.

1954a. Beginsels van Protestantse Kerkbou. Pretoria: HAUM.

1954b. Marriage and family life in Ugaritic literature. London: Luzac \& Co.

1956a. De verscheurde stad: Oud Jeruzalem waar de Joden niet kunne komen. Den Haag: J N Voorhoeve.

1956b. Die plek van Israel in ons teologies-kerklike beskouing. HTS 12, 97-i09.

1956c. 'n Besoek aan Bethlehem. Die Hervormer, Januarie 1956, bl 20-21.

1956d. 'n Arabiese grammatika in Afrikaans. TWK, April 1956, 14-19.

1956e. Vanaf die begin tot die jaar 70 n C. Lantern 6, 5-9.

1957a. De Rol der Lofprijzingen. Een der Dode Zee rollen vertaald en toegelicht. Baarn: Bosch \& Keuning.

1957b. The origin of the title 'the king's friend'. JNES 1957, 118-123.

1958a. By die vertrek van prof Gemser. Almanak, 58-69.

1958b. Is diere in die paradys verskeur? Die Hervormer, Januarie 1958, bl 6, 7.

1958c. Oor die erfsonde. Die Henormer, Maart 1958, bl 8-9.

1958d. Preekstoel en nagmaalstafel. Die Hervormer Mei 1958, bl 8.

1958e. Die oorsprong van die woord 'Bybel'. Die Henormer, Augustus 1958, bl 1011.

1958f. The Canaanites in the Book of Genesis. OTS 12, 182-213.

1958g. Jüdische Diaspora. RGG ${ }^{3}$, Tübingen.

1958h. Judaism and Islam. South African Jewish Observer, September 1958, 27, 54.

1958i. Historiese en geografiese name in die boek van die Psalms. HTS, 1-12.

1958j. Kiest dan heden wie gij dienen zult. $K \& T$ 9, 210-218.

1958k. Die stand van die Ou Testamentiese wetenskap, insonderheid in Suid-Afrika. HTS 14, 41-52.

19581. Die formule 'Jy is my...ek is jou'. HTS 14, 130-140.

1958m-r. 1 Konings, 2 Konings, 1 Kronieke, 2 Kronieke, Esra, Nehemia. Bybel met verklarende aantekeninge. Deel I, 685-991. Kaapstad: VPU.

1958s. Esegiël: Bybel met verklarende aantekeninge. Deel II, 1747-1857. Kaapstad: VPU.

1959a. Mate, gewigte en geld in die Ou Testament. Bybel met verklarende aantekeninge. Deel III, 823-826. Kaapstad: VPU.

1959b. Theologie van de filoloog I. God als werkwoord. $K \& T 10,65-76$.

1959c. Theologie van de filoloog II. God als meervoud. $K \& T 10,65-76$. 
1959d. Theologie van de filoloog III. God als telwoord. $K \& T$ 10, 201-209.

1959e. Die uitdrukking 'Man van God' in die Bybel. HTS 15, 133-149.

1959f. (Anoniem) A van Deursen en G Meima 9159. Bijbelse Aardrykskunde (Vertaling en verwerking).

1959g. (Anoniem) DJ van Katwijk en G Meima 1959. Bybelse Oudheidkunde (Vertaling en uitbreiding).

1959h. Die Moeder van die Here. Die Hervormer, Desember 1959, bl 3-4.

1959i. The title 'Judge'. OTWSA 1959, 41-50.

1960a. Geloofshelde onder die Ou Verbond. Pretoria: HAUM.

1960b. The armed forces of Israel under Saul and Dawid. OTWSA 1960, 55-66.

1960c. Abu-Bakr and Arabic-Afrikaans Literature, in Brandel-Syrier, M (ed), The religious duties of Islam as taught and explained by Abu Bakr Effendi, v-iv. Leiden: Brill.

1960d. Die gemeenskap van die heiliges en die kleurvraagstuk: Vertraagde Aksie, 36-47. Pretoria: NG Kerk Uitgewers.

1960e. Die Voortrekkerwysies in ons kerkdienste. Die Hervormer, September 1260, bl 17; Oktober 1960, bl 10-11.

1960f. Een kanttekening bij het artikel van A F J Klijn. NTT 14, 237-239.

1961a. Slae in die lug. Die Henormer, Maart 1961, bl 13-14.

1961b. Die Bondsboek en die reg van Gosen. HTS 16, 329-343.

1961c. Literary Criticism of Ezekiel as a theological problem. OTWSA 1961, 2437.

1961d. Oortuiging en verdraagsaamheid. HTS 16, 112-122.

1961e. Jerusalem discovery recalls Isaiah's criticism. SA Jewish Observer: New Year Annual 1961, 22-23.

1961f. Die Nederduitsch Hervormde Kerk van Afrika en die kleurscheidslyn. $K$ \& $T$ 12, 151-165.

1961g. Ter inleiding van die Gemser-nommer. HTS 16, 159-260.

1962a-f. Azazel, Balaam, Footman, Friend of the Bridegroom, Book of Joshua, Law. New Bible Dictionary. London.

1963a. The Abisha-scroll of the Samaritans. SA Jewish Observer, April 1962, 10, 64.

1963b. Gedachten in Chorazin. Kerk en Theologie 1963, 157-168.

1963c. 'n Leek tussen die boom en die bas. Standpunte 1963, 4-13.

1963d. Is dit die manier? Die Henormer, Junie 1963, bl 7.

1963e. Kerk en geheime organisasie.

1964. Judge Shamgar. VT 14, 294-309.

1965. The Fourth World Congress of Jewish Studies, Jerusalem 1965. Jewish Affairs, Sept 1965, 14-17. 
1966a. Nisibis: The oldest university. Cape Town: University of Cape Town.

1966b. Hosea and Canticles. OTWSA 1966, 85-89.

1966c. The southern kingdom in Hosea. OTWSA 1966, 100-111.

1966d. Isaac in Amos. OTWSA 1966, 157-165.

1966e. Amos' geographic horizon. OTWSA 1966, 166-169.

1966f. Die uitstraling van die Sumeriese kultuur, in Cronje, G (red), Kultuurbemvloeding in die oudheld, 10-23. Pretoria.

1966g. A forgotten god: Lah. Studia Biblica et Semitica Theodoro Christiano Vriezen dedicata, 318-326. Wageningen: Veenman \& Zonen.

1966h. Preeksketse oor Amos 7:14; Hosia 1:26; Jes 6:8; Jer 1:12. Postille 19661967.

1967a. Genesis I. Nijkerk: Callenbach.

1967b. Genesis II. Nijkerk: Callenbach.

1967c. Levend verleden: Een zwerftocht door Noord-Israël. Nijkerk: Callenbach.

1967d. How do books of the Bible commence? OTWSA 1967, 132-141.

1967e. Some geographical remarks on Jonah. OTWSA 1967, 83-92.

1967f. Church and state according to the OT prophets. Ministry 7, 155-159.

1967g. Halo in the courtier's language in ancient Israel. Fourth World Congress of Jewish Studies, Papers 1, 137-140.

1967h. Paycal formations in Ugaritic and Hebrew nouns. JNES 26, 289-295.

1968a. Berend Gemser 1890-1962: A biographical sketch. Adhuc Loquitur, 1-11. Leiden: Brill.

1968b. An exegetical study of Psalm 49. Report of the Missiological Institute, Mapumulo, on concepts of death and funeral rites, 2-13.

1968c. Piercing the veil: Some Old Testament conceptions of death. Report of the Missiological Institute, Mapumulo, on concepts of death and funeral rites, 15-20.

1968d. Abu Bakr Effendi. SABW 1, 4-5.

1969a. Jenuzalem door de eeuwen heen. Baarn: Hollandia.

1969b. God's election in the Old Testament. Ministry 9, 51-57.

1969c. Die Psalms as 'n banier. St Andrew's News, October 1969, 4-5.

1969d. The alphabetic hymn in Nahum 1. OTWSA 1969, 33-45.

1969e. The Moslem attitude to Jerusalem. SA Jewish Observer: New Year Annual $1969,10,11,42$.

1969f. The 'Cheese-mongers' Valley in Old Jerusalem. Barkai, September 1969, 136-137.

1970a. Yamma's texts UT 129, 137 and 68. Uganit-Forschungen 2, 251-268. 
1970b. Die epos in die Ou Nabye Ooste, in Cronje, G (red), Die epos, 1-17. Pretoria.

1970c. De sleutelmacht: Een exegese van Matth 16:19. $K \& T$ 1970, 247-260.

1971a. Some reflections on the formation of the feminine in Semitic languages, in Goedicke, H (ed), Near Eastern Studies in honor of WF Albright, 421-431. Baltimore: Johns Hopkins Press.

1971b. Akkadian dullu(m) as a loan-word in West-Semitic languages. JNSL 1971, 51-58.

1971c. CTA 32: A prophetic liturgy. Ugarit-Forschungen 3, 235-248.

1971d. The fire in Yammu's palace. Ugarit-Forschungen 3, 249-252.

1971e. Motivated Interrogative Sentences in Biblical Hebrew. Semitics 2, 1971/ 1972, 143-149.

1971f. Mappam...Poeni sibi vindicant, in Kriel, D M (red), Pro munere grates, 191199. Pretoria.

1972. Jeremia I. Nijkerk: Callenbach.

1973a. Temporary henotheism, in Beek, M A ea (reds), Symbolae biblicae et mesopotamicae FM Th de Liagre Böhl dedicatae, 341-348. Leiden: Brill.

1973b. Isaiah 28:9-13: An attempt to give a new interpretation. $Z A W 85,332-339$.

1974a. Jeremia II. Nijkerk: Callenbach.

1974b. In gesprek met Islam oor die Moslembelydenis. Bloemfontein.

1974c. Jeremia III en Klaagliederen. Nijkerk: Callenbach.

1974d. The name Nebuchadnezzar, in Heerma van Voss, M S H G e a (eds), Travels in the World of the Old Testament. Studies presented to prof $M A B$ Beek, 223-229. Assen.

1974e. The etymology of yayin, 'wine'. JNSL 3, 76-84.

1975a. The inner cohesion of the Book of Malachi. OTWSA 1975, 27-40.

1975b. The year of Jeremiah's birth. OTWSA 1975, 75-86.

1975c. Some remarks on the Ammon Citadel inscriptions. Bibliotheca Orientalis $32,5-8$.

1975d. A guestroom for Ilu and its furniture. Ugarit-Forschungen 7, 469-476.

1975e. A systematic approach to CTA 5, 1 1-8. Ugarit-Forschungen 7, 477-482.

1975f. Een geval van Nah-erwartung zonder en met 'gemeentetheologie'. $K \& T$ 26, 43-50.

1976a. Zeg tot mijn broeder, dat hij de erfenis met mij dele. $K \& T 27,19-23$.

1976b. 'Roof' in Philippenzen 2:6. $K \&$ T 27, 199-204.

1976c. De binnenkamer. $K \& T 27,283-289$.

1976d. Year of Jubilee. The Interpreter's Dictionary of the Bible (Supplementary Volume), 496-498. Nashville. 
1976e. Boset as substitute for ba'al. OTWSA 1977, 1-9.

1977a. The year of the Jubilee, in and outside the Pentateuch. OTWSA 1977, 75 85 .

1977b. Whate'er my God ordains is right. A figure of style in the Book of Jeremiah. Semitics 5, 1-8.

1977c. Siggin and siggil in the Qur'an. Die Welt des Orients 9, 99-103.

1978a. Die God van die Ou Testament. Pretoria: Universiteit van Suid-Afrika.

1978b. Die Spreukedigter se uitsprake in verband met die huwelik, in Van Rensburg, W C J (red), En as ek die liefde nie het nie. Pretoria.

1978c. Het opschrift van het Evangelie naar Marcus. $K \& T 29,13-18$.

1979a. Abu Bakr se 'Uiteensetting van die godsdiens'. Amsterdam.

1979b. 'n Nuwe lied. Die betekenis en nawerking van 'n Bybelse uitdrukking, in Loader, J A (red), 'n Nuwe lied vir die Here. Pretoria: KITAL.

1979c. Isaiah 2:4: Parallels and contrasts. OTWSA 1979/1980, 230-239.

1979d-g. Basin, Bread, Building, Cart. The International Standard Bible Encyclopaedia I. Grand Rapids.

1979h. The origin of the name Tyropoeon in Jerusalem. $Z A W 91,170-176$.

1979i. The root k-t-r and its derivatives in Ugaritic Literature. Ugarit-Forschungen 11, 739-744.

1979j. Respect of animals in Islam. Ritual slaughtering without cruelty. Arabic Studies 3, 5-7.

1979k. Adunata in de Evangeliën: met troost voor exegeten. $K \& T 30,9-18$.

1980a. Dawqa! - its Biblical precedents. Semitics 7, 40-49.

1981. Waarom vieren wij geen loofhuttenfeest? $K \& T 32,299-303$.

1982a. Isaiah 2:4: Parallels and contrasts. OTWSA 1982, 230-239.

1982b. De Tafel, en twee stijlbloempjes van de tafel. $K \& T 33,301-308$.

1982c. Job I. Nijkerk: Callenbach.

1982d. Calaeno se doemwoord en die vervulling daarvan. ACL 25, 141-144.

1982e. Job 31:38-40 in Ugaritic Light. Semitics 8, 30-42.

1983. Job II. Nijkerk: Callenbach.

1984. Job: Een praktische Bijbelverklaring. Kampen: Kok. 